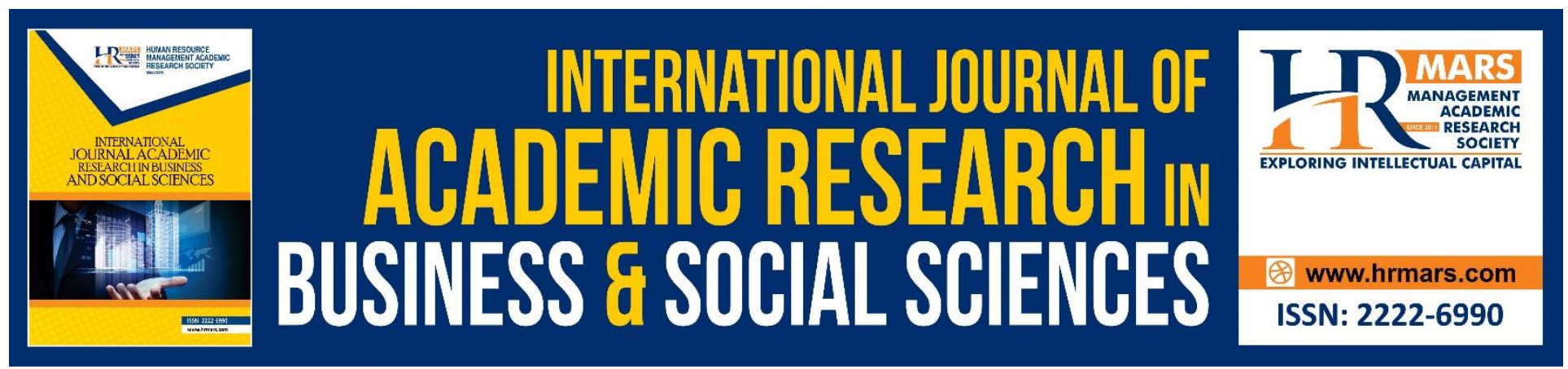

\title{
Developing And Validating the Measurement Model for Employee Engagement Construct Using Confirmatory Factor Analysis
}

Oh Zi Jian, Khoo Yin Yin, and Marinah Awang

To Link this Article: http://dx.doi.org/10.6007/IJARBSS/v10-i8/7662

DOI:10.6007/IJARBSS/v10-i8/7662

Received: 18 May 2020, Revised: 20 June 2020, Accepted: 25 July 2020

Published Online: 13 August 2020

In-Text Citation: (Jian, Yin, and Awang, 2020)

To Cite this Article: Jian, O. Z., Yin, K. Y., and Awang, M. (2020). Developing And Validating the Measurement Model for Employee Engagement Construct Using Confirmatory Factor Analysis. International Journal of Academic Research in Business and Social Sciences. 10(8), 924-941.

Copyright: (C) 2020 The Author(s)

Published by Human Resource Management Academic Research Society (www.hrmars.com)

This article is published under the Creative Commons Attribution (CC BY 4.0) license. Anyone may reproduce, distribute, translate and create derivative works of this article (for both commercial and non-commercial purposes), subject to full attribution to the original publication and authors. The full terms of this license may be seen at: http://creativecommons.org/licences/by/4.0/legalcode

Vol. 10, No. 8, 2020, Pg. 924 - 941

http://hrmars.com/index.php/pages/detail/IJARBSS

JOURNAL HOMEPAGE

Full Terms \& Conditions of access and use can be found at http://hrmars.com/index.php/pages/detail/publication-ethics 


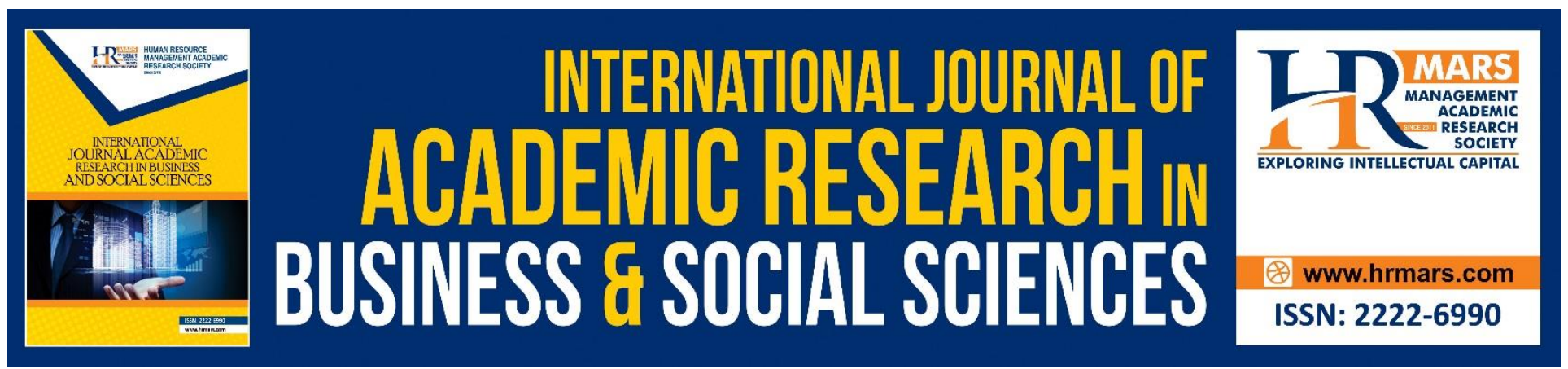

\title{
Developing And Validating the Measurement Model for Employee Engagement Construct Using Confirmatory Factor Analysis
}

\author{
Oh Zi Jian ${ }^{1}$, Khoo Yin Yin², and Marinah Awang ${ }^{3}$ \\ 1 \& 3 Department of Educational Management, Faculty of Management and Economics, Sultan \\ Idris Education University, 35900 Tanjung Malim, Perak, Malaysia, ${ }^{2}$ Department of Economics, \\ Faculty of Management and Economics, Sultan Idris Education University, 35900 Tanjung Malim, \\ Perak, Malaysia. \\ E-mail: ohzijian@gmail.com
}

\section{Abstract}

The purpose of the study is to develop and validate the instruments designed to measure employee engagement construct. The pilot study used the structured survey randomly sampled 300 lecturers. The effectiveness of measuring items and the dimensionality of the construct determined by the Exploratory Factor Analysis (EFA) procedure. At last, utilizing the recently developed instruments, the field study attained a random sample of 401 lecturers to survey employing the structured survey. The field data were used via the Confirmatory Factor Analysis (CFA) procedure to validate the instruments. The EFA procedure identified three components that emerged from the items. The CFA procedure validated the uni-dimensionality, validity, and reliability of the instruments measuring employee engagement construct. The finding indicated that the employee engagement construct measurement model accomplished the requirement for construct validity and reliability and ought to be applied for research in the future. This study developed instruments specifically for assessing employee engagement among vocational lecturers in the North Zone of Malaysia. Future researchers could foster widen the instrument showed in this study by cross-surveying across the different Zone of Malaysia and compared with other related EE instruments.

Keywords: Employee Engagement, Vocational College, Exploratory Factor Analysis, Confirmatory Factor Analysis.

\section{Introduction}

Employee engagement (EE) is the key factor in attaining targeted vision and mission and has a great impact on organizations, institutions, and companies. Engagement of employees towards an organization's leadership is critical to ensuring excellent work performance. EE is an essential component of an organization because employees involved in organizational goals are expected to be more productive and more sensitive to achieving higher contribution levels than workers with no 
INTERNATIONAL JOURNAL OF ACADEMIC RESEARCH IN BUSINESS AND SOCIAL SCIENCES Vol. 10, No. 8, 2020, E-ISSN: 2222-6990 @ 2020 HRMARS

value for involvement (Mora, Hakim, Agustriyana, 2020; Tritch, 2003; Yildiz, Temur, Beskese \& Bozbura, 2020). Furthermore, EE is an individual's physical, emotional, cognitive, and intellectual involvement. The role of an active and enthusiastic lecturer in the higher education sector in today's stormy environment is extremely undoubted. An engaged lecturer will exhibit a high degree of commitment and involvement in the profession resulting in quality results (Madhavi Latha, Ramakrishna \& Mohanthi, 2020). Meanwhile, lecturers with a high degree of engagement to their work will have positive feelings that will guide them to recuperate their quality through imaginative and explorative thinking, incorporating innovating in teaching and learning activities (linasikin, Murni \& Akbar, 2019).

However, the issue of EE requires more attention due to current circumstances showing 13 percent of worldwide employees involved (Gallup, 2013) and it is reflecting a low level of employee engagement (Nienaber, 2019). On the other hand, there is a more alarming rate of EE in Malaysia where 8 percent of the study shows no direct engagement, 11 percent with engagement compared to a high 81 percent with less involvement. Besides, structures of the current education system involving frequent changes in educational policy increased administrative demands, insufficient autonomy of lecturers, a focus on performativity and sparse material constraints may lead to lecturer disappointment and, consequently, low work commitment and job satisfaction (Buric, Cvijetovic \& Macuka, 2017). Abundant problems are underlined regarding the lecturers' performance because they are doing multitasking against the principles of the conventional role of teaching (Kola \& Challapalli, 2019). Vocational college lecturers experience the ill effects of stress and burnout issues that can cause significant workplace issues (Janssen, Heerkens, Van Der Heijden, Korzilius, Peters \& Engels, 2020). Therefore, EE is a critical issue to be dealt with in the public sector.

Even though EE have been assessed and clarified to some extent in several previous studies (Abror, Patrisia, Syahrizal, Sarianti, \& Dastgir, 2020; Atcıoğlu \& Köse, 2018; Ibnu Ruslan, Islam, Mohd Noor \& Norsiah Mat, 2016; linasikin, Murni \& Akbar, 2019; Kaldeen \& Maran, 2020, Muthuveloo, Basbous, Teoh \& Choi, 2013; Puteh, Kaliannan \& Alam, 2015; Rashid \& Mohd Harif, 2015), notwithstanding, the literature review shows that there is still no regular understanding between the researchers as the terms of aspects and items which should be used to access EE. Nonetheless, though wide-ranging research has been conducted on EE, current studies seem to ignore some of the crucial factors that can assist with giving a precise and point by point comprehension of the number of aspects as well as items of EE. To give an increasingly complete understanding of the EE measurement model, this study plans to develop and validate the instruments for measuring $\mathrm{EE}$ construct among vocational colleges' lecturers in Malaysia. The exploratory factor analysis used to acquire validity and reliability and the right items of measuring instruments (Hoque \& Awang, 2016a, Hoque \& Awang, 2016b, Hoque \& Awang, 2016c). Whereas validity and composite reliability of the construct will be validated through confirmatory factor analysis. Therefore, the objective of this study is:

- to explain how to develop and validate the instruments intended to gauge employee engagement construct.

\section{Literature Review \\ Definition of Employee Engagement}

Kahn (1990) is the initial scholarly canvasser to exploit the phrase of EE and saw it as a stage of devotion and involvement of employees towards its organization. Besides, he conceptualizes engagement as harnessing oneself in terms of physical, cognitive, and emotional for their work roles, 
to articulate their role performances. While Kinicki and Fugate (2016) having the same thought and stated EE as the removal of an organization gives itself job roles, commitment, individuals and expresses itself physically, intellectually, and emotionally all through the implementation of roles. Meanwhile, Harter, Schmidt, and Hayes (2002) agree with the opinion of EE by Kahn and defined it as the participation and gratification of a person with the spirit of working. But Chartered Institute of Personnel and Development (CIPD) (2007) stated EE as an amalgamation of obligation to the organization and the value of being willing to help his colleagues. Soon, EE claimed by researchers as a sincere and wide-ranging relationship with companies that result in a willingness to act unexpectedly to help the organization achieve success (Gebauer \& Lowman, 2009), and it also affirmed as objectives and labor aimed at others through personal initiative, suitability, craft and persistence leading towards the objectives of the organization (Macey, Schneider, Barbera \& Young, 2009).

Engagement of employees is important to urge innovation and thoughts and to make sure that staff is fully engaged in their jobs, inspiration, and excitement in the organization. An organization needs enthusiastic employees (Bohlander \& Snell, 2013) since they have solid emotions, eagerness, and center which will make them progressively dedicated to their superiors and invest more energy in their work (Dessler, 2013). Employees that engaged in their work will often be more attentive, have ambition, be optimistic, and concentrate their energies on meeting organizational targets (Macey et al., 2009). All in all, a few things that can enhance EE, among others, will increase employee rewards, strong remarks, and empowering criticism from colleagues or superiors on a specific day (Schaufeli \& Baker, 2010).

Employees are divided into three types. The first type is engaged employees, they are constructors who continually aspire to achieve success within their positions. Next, not engaged employees, where they are concentrating on the duties they have set out, rather than the organization's goals. They do what he tells them to do. Lastly, actively disengaged employees, where they are hazardous people who perform well in the organization as well as discourage the performer (Gallup, 2002). Hence, keeping the employees engaged is very important otherwise, they may be a threat to the organization.

\section{Methods}

In order to determine a valid and reliable measure for the EE construct, a cross-sectional research design was applied. The population for this study is the lecturers who are teaching in the vocational college in North Zone of Malaysia, which is Penang, Kedah, Perlis, and Perak. The data was carried out in two phrases, specifically pilot study and field study. The stratified random sampling method was employed in both stages to pick out a sample of 300 and 401 respondents, respectively. The data were gathered using a structured survey questionnaire.

\section{Research Instrument}

For developing the EE measuring instrument, the study adapted from Schaufeli, Salanova, Gonzalez-Roma, and Bakker (2002) and finally produced three constructs, namely dedication, absorption, and vigor. By developing a structured questionnaire, data is collected to measure EE construct in this study, which contains fourteen (14) items measured using a five-point interval scale. 
INTERNATIONAL JOURNAL OF ACADEMIC RESEARCH IN BUSINESS AND SOCIAL SCIENCES Vol. 10, No. 8, 2020, E-ISSN: 2222-6990 @ 2020 HRMARS

\section{Exploratory Factor Analysis (EFA)}

Before continuing to result in the analysis of Confirmatory Factor Analysis (CFA), EFA was performed (Nasir, Mohamad, Ghani \& Afthanorhan, 2020). EFA performs a vigorous position to explore the interrelationships among the items of three aspects of EE. In the meantime, a set of items compacted into a littler arrangement of blend factors with a base loss of data which consumed by EFA and can be understood much clearly and significantly (Duntemen, 1989; Field, 2006; Lewis-Beck, 1994) and thus placed the basis of structural equation modeling (Hair et al., 2006). Meanwhile, it is a standard method of developing an instrument to gauge the data set for its appropriateness (KungTech, Omar, Yassin, Mustafa, Abdullah, Rahmatullah \& Samuri, 2019).

By adapting and modifying instruments developed by previous researchers, the items used to match current research. The researcher should conduct the EFA procedure, if they regulate the instruments earlier prepared by the researchers and alter proclamations applicable to existing research (Awang, 2012; Awang, Lim \& Zainudin, 2018; Hoque \& Awang, 2016b; Hoque \& Awang, 2016c; Hoque et al., 2017b). It may be due to the existing field of study might be diverse from preceding studies, or the existing research population is widely dissimilar from prior studies in the point of view of demographic aspect. As a result, there might be some items that may have been designed in the past, and may no longer be appropriate for current research. Hence, the value of internal reliability for the existing instrument and the new Cronbach Alpha value need to be reanalyzed by the researchers (Awang, 2012; Awang, Lim \& Zainudin, 2018; Baistaman, Awang, Afthanorhan \& Abdul Rahim, 2020; Hoque \& Awang, 2016b; Hoque et al. 2017a; Hoque et al., 2017c; Hoque et al., 2018a, Hoque et al., 2018c). The designated items carry each other while measuring the construct indicated by the internal reliability (Rahlin, Awang, Afthanorhan \& Aimran, 2019).

\section{Findings and Discussion}

The findings and discussion of this study will be deliberated as follow:

\section{Results of Exploratory Factor Analysis}

To decide the fundamental items and recommend aspects of the EE construct, and also to validate the feature of the instrument, three hundred (300) respondents have been used in this study. There were three aspects and 14 adopted items for the EE construct. Among 14 items of EE construct, a total of 7 items, three items, and three items belong to dedication, absorption, and vigor, respectively, and one item has been deleted. The result is consequently displayed as follows:

Table 1: KMO and Bartlett's Test for the items of EE Construct

\begin{tabular}{lll}
\hline Kaiser-Meyer-Olkin Measure of Sampling Adequacy & & .886 \\
\hline & Approx. Chi-Square & 2120.117 \\
Barlett's Test of Sphericity & $\mathrm{df}$ & 91 \\
& Sig. & .000 \\
\hline
\end{tabular}

The index of KMO that over 0.6 is regularly acknowledged. In Table 1 above, the KMO value of 0.886 is outstanding as it surpasses the suggested value of 0.6 . Furthermore, the significance value of Bartlett's Test of Sphericity must not be as much of 0.05 for the factor analysis to be adequate. Based on Table 1, Bartlett's Test significance value is 0.000 , which meets the entailed significance value of the smaller amount of 0.05 (Awang, 2012; Awang, Lim \& Zainudin, 2018; Hoque \& Awang, 2016b; Hoque et al., 
INTERNATIONAL JOURNAL OF ACADEMIC RESEARCH IN BUSINESS AND SOCIAL SCIENCES Vol. 10, No. 8, 2020, E-ISSN: 2222-6990 @ 2020 HRMARS

2017b). Hence, data within the KMO values, approximately 1.0, and Bartlett's test significance value nearly to 0.0 can be expressed sufficiently. In this manner, the data can be applied, and the reduction procedure can be continued.

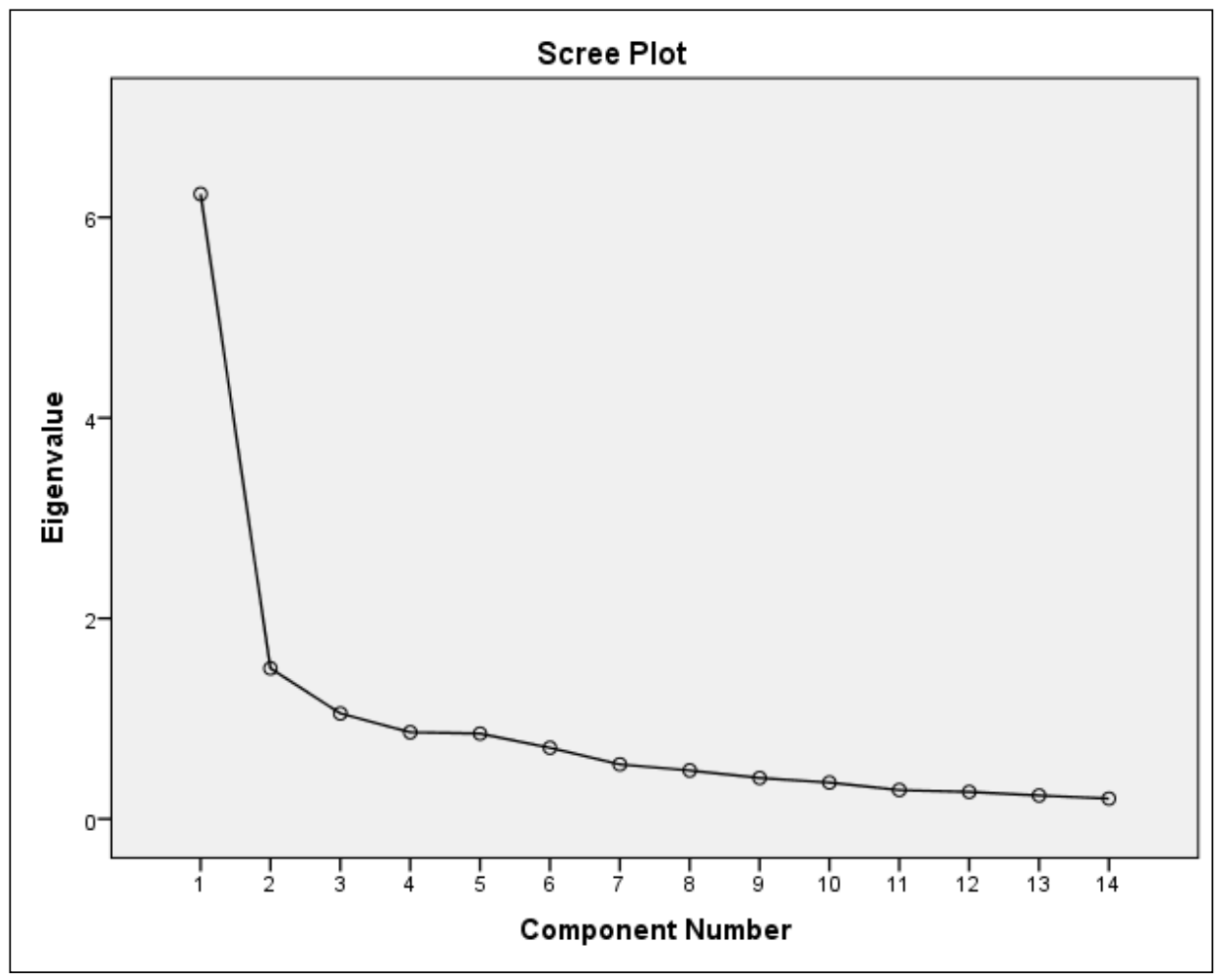

Figure 1: Three component extraction

Table 2: Total Variance Explained for EE Construct

\begin{tabular}{|c|c|c|c|c|c|c|c|c|c|}
\hline \multirow[t]{3}{*}{ Comp. } & \multicolumn{3}{|c|}{$\begin{array}{l}\text { Initial } \\
\text { Eigenvalues }\end{array}$} & \multicolumn{3}{|c|}{$\begin{array}{l}\text { Extraction Sums of } \\
\text { Squared Loadings }\end{array}$} & \multicolumn{3}{|c|}{$\begin{array}{l}\text { Rotation Sums of } \\
\text { Squared Loadings }\end{array}$} \\
\hline & Total & $\% \quad$ of & Cumulative & Total & $\% \quad$ of & Cumulative & Total & $\% \quad$ of & Cumulative \\
\hline & & Variance & $\%$ & & Variance & $\%$ & & Variance & $\%$ \\
\hline 1 & 6.234 & 44.525 & 44.525 & 6.234 & 44.525 & 44.525 & 3.799 & 27.134 & 27.134 \\
\hline 2 & 1.501 & 10.724 & 55.249 & 1.501 & 10.724 & 55.249 & 2.517 & 17.979 & 45.113 \\
\hline 3 & 1.052 & 7.515 & 62.764 & 1.052 & 7.515 & 62.764 & 2.471 & 17.651 & 62.764 \\
\hline 4 & .864 & 6.168 & 68.933 & & & & & & \\
\hline 5 & .850 & 6.074 & 75.007 & & & & & & \\
\hline 6 & .709 & 5.062 & 80.069 & & & & & & \\
\hline 7 & .544 & 3.883 & 83.952 & & & & & & \\
\hline 8 & .483 & 3.452 & 87.405 & & & & & & \\
\hline 9 & .408 & 2.917 & 90.322 & & & & & & \\
\hline 10 & .362 & 2.587 & 92.908 & & & & & & \\
\hline 11 & .288 & 2.054 & 94.962 & & & & & & \\
\hline 12 & .269 & 1.921 & 96.883 & & & & & & \\
\hline 13 & .234 & 1.671 & 98.554 & & & & & & \\
\hline 14 & .202 & 1.446 & 100.000 & & & & & & \\
\hline
\end{tabular}

Note: Principal Component Analysis as the extraction method 
INTERNATIONAL JOURNAL OF ACADEMIC RESEARCH IN BUSINESS AND SOCIAL SCIENCES

Vol. 10, No. 8, 2020, E-ISSN: 2222-6990 @ 2020 HRMARS

An extraction process of items need to be carried out to diminish them into an adaptable number before further analysis, is known as total variance explained. On top of it, components with eigenvalues higher than 1.0 are extracted into different components (Awang, 2012; Awang, Lim \& Zainudin, 2018; Hoque \& Awang, 2016b; Pallant, 2007). As can be perceived in Table 2, EFA has extracted three aspects, or components of EE construct with eigenvalue $6.234,1.501$, and 1.052 for component numbers 1,2 , and 3 individually disclosed by the output. This designates that the items are convened into three aspects or components and could be reflected for further analysis. The total variance explained of 62.764 presented in Table 2.

Table 3: Rotated Component Matrix of EE Construct

\begin{tabular}{|c|c|c|c|c|}
\hline \multirow{2}{*}{$\begin{array}{l}\text { Item } \\
\text { Code }\end{array}$} & \multirow[t]{2}{*}{ Statement } & \multicolumn{3}{|c|}{ Component } \\
\hline & & 1 & 2 & 3 \\
\hline EE1 & I am proud of the work that I do & .780 & & \\
\hline EE2 & $\begin{array}{l}\text { I find the work that I do full of meaning and } \\
\text { purpose }\end{array}$ & .756 & & \\
\hline EE3 & Time flies when I am working & .683 & & \\
\hline EE4 & I am enthusiastic about my job & .644 & & \\
\hline EE5 & $\begin{array}{l}\text { At my work, I always persevere, even when } \\
\text { things do not go well }\end{array}$ & 616 & & \\
\hline EE6 & To me, my job is challenging & .606 & & \\
\hline EE7 & I get carried away when I am working & 605 & & \\
\hline EE8 & My job inspires me & Deleted & & \\
\hline EE9 & $\begin{array}{l}\text { I can continue working for very long periods at a } \\
\text { time }\end{array}$ & & .867 & \\
\hline EE10 & At my job, I am very resilient, mentally & & .722 & \\
\hline EE11 & $\begin{array}{l}\text { When I am working, I forget everything else } \\
\text { around me }\end{array}$ & & .666 & \\
\hline EE12 & $\begin{array}{l}\text { When I get up in the morning, I feel like going to } \\
\text { work }\end{array}$ & & & .887 \\
\hline EE13 & At my work, I feel bursting with energy & & & .789 \\
\hline EE14 & At my job, I feel strong and vigorous & & & 613 \\
\hline
\end{tabular}

Extraction Method: Principal Component Analysis

Rotation Method: Varimax with Kaiser Normalization

The result in Table 3 indicates that three components have been extracted by the EFA procedure. Several numbers of items with their separate factor loading for each component. For those item denotes the helpfulness in measuring the specific construct which having factor loading exceeding 0.6, will be preserved (Awang, 2012; Awang, Lim \& Zainudin, 2018; Awang et al., 2017a; Awang et al., 2017b; Hoque \& Awang, 2016b; Hoque \& Awang, 2019). However, the factor loading of Item EE8 is less than 0.6 , therefore it is removed due to this item do not contribute to accessing the planned construct. 
INTERNATIONAL JOURNAL OF ACADEMIC RESEARCH IN BUSINESS AND SOCIAL SCIENCES

Vol. 10, No. 8, 2020, E-ISSN: 2222-6990 @ 2020 HRMARS

Table 4: Rotated Component Matrix of EE Construct (After the deletion process)

\begin{tabular}{|c|c|c|c|c|}
\hline \multirow{2}{*}{$\begin{array}{l}\text { Item } \\
\text { Code }\end{array}$} & \multirow[t]{2}{*}{ Statement } & \multicolumn{3}{|c|}{ Component } \\
\hline & & 1 & 2 & 3 \\
\hline EE1 & I am proud of the work that I do & .780 & & \\
\hline EE2 & $\begin{array}{l}\text { I find the work that I do full of meaning and } \\
\text { purpose }\end{array}$ & .756 & & \\
\hline EE3 & Time flies when I am working & 683 & & \\
\hline EE4 & I am enthusiastic about my job & .644 & & \\
\hline EE5 & $\begin{array}{l}\text { At my work, I always persevere, even when } \\
\text { things do not go well }\end{array}$ & 616 & & \\
\hline EE6 & To me, my job is challenging & .606 & & \\
\hline EE7 & I get carried away when I am working & .605 & & \\
\hline EE9 & $\begin{array}{l}\text { I can continue working for very long periods at a } \\
\text { time }\end{array}$ & & .867 & \\
\hline EE10 & At my job, I am very resilient, mentally & & .722 & \\
\hline EE11 & $\begin{array}{l}\text { When I am working, I forget everything else } \\
\text { around me }\end{array}$ & & .666 & \\
\hline EE12 & $\begin{array}{l}\text { When I get up in the morning, I feel like going to } \\
\text { work }\end{array}$ & & & .887 \\
\hline EE13 & At my work, I feel bursting with energy & & & .789 \\
\hline EE14 & At my job, I feel strong and vigorous & & & .613 \\
\hline
\end{tabular}

Extraction Method: Principal Component Analysis

Rotation Method: Varimax with Kaiser Normalization

The selected item to be applied for the study is shown in Table 4 after the deletion process. Consequently, these 13 items within factor loading that exceed 0.6 that displayed in the aboverotated component matrix, will be cogitated for further analysis under three aspects or components of the EE construct

\section{Reliability Analysis for the Measuring Item of EE}

The technique that needs to be implemented to evaluate the measuring item under each construct and assess the degree to prove the items are error-free called reliability analysis. The reliability of items is measured by using the renowned value of Cronbach's Alpha. Yet, the acquiescence value of Cronbach's Alpha as an indicator of internal consistency items diverge by numerous researchers. For validating internal consistency reliability, Cronbach's Alpha of greater than 0.5 is recommended (Kerlinger \& Lee, 2000). Besides, Cronbach's Alpha of 0.6 or greater presents a reliable measure of internal consistency (Awang, 2012; Awang, Lim \& Zainudin, 2018; Hair et al., 1998; Hoque \& Awang, 2016b; Nunnally \& Bernstein, 1994; Nunnally, 1978; Sekaran \& Roger, 2013; Darwish, Abdo, \& AlShuwaiee, 2018) whereas the value of 0.7 indicates that the instrument holds a high-reliability standard (Hoque \& Awang, 2019; Hoque et al., 2018c) and it applied in this study. 
INTERNATIONAL JOURNAL OF ACADEMIC RESEARCH IN BUSINESS AND SOCIAL SCIENCES Vol. 10, No. 8, 2020, E-ISSN: 2222-6990 @ 2020 HRMARS

Table 5: Reliability Statistics for the three Components of EE Construct

\begin{tabular}{llll}
\hline Component & $\begin{array}{l}\text { Number of items in a } \\
\text { component }\end{array}$ & $\begin{array}{l}\text { Cronbach's } \\
\text { Alpha }\end{array}$ & $\begin{array}{l}\text { Cronbach's Alpha } \\
\text { based } \\
\text { standardized item }\end{array}$ \\
\hline 1 & 7 & .852 & .852 \\
2 & 3 & .700 & .700 \\
3 & 3 & .827 & .827 \\
\hline
\end{tabular}

As displayed in Table 5, there are seven items, three items, and three items for component 1 (dedication), component 2 (absorption), and component 3 (vigor) of EE construct, and its Cronbach's Alpha is $0.852,0.700$, and 0.827 correspondingly. It showed a high-reliability standard for the three aspects or components of the EE construct, which have surpassed the needed value of 0.6. Thus, the extracted aspects or components with their particular items are reliable and suitable to measure the EE construct. Hence, employing those items for measuring EE constructs in future researches.

\section{Findings for the field study Confirmatory Factor Analysis (CFA)}

CFA is applied for authenticating the factor loading and measurement that included. Factor loadings and fitness indexes play a significant role in the CFA approach. Additionally, the fitness index unable to achieve the requirement whenever the factor loading is in high value which indicates the data is incompetent to be accepted.

Absolute fit, incremental fit, and parsimonious fit are three categories included in the measurement of the fitness index. However, the researcher able to choose any fitness as long as each category is included, or at least one fitness index from each category model fit is used (Afthanorhan, 2013).

Meanwhile, if the fitness indexes achieved the requirements from the three Model Fit aspects which are Absolute Fit (RMSEA <0.08), Incremental Fit (CFI and TLI >0.9) and Parsimonious Fit (Chisq/df <5.0) respectively, the specific latent construct is counted valid (Awang, Lim \& Zainudin, 2018)

Next, there are three types of validity explicitly construct validity, convergent validity, and discriminant validity need to be achieved by the measurement model of latent constructs which measure by Fitness Indexes of the Measurement Model, Average Variance Extracted (AVE), and Discriminant Validity Index Summary individually (Mohamad, Ali \& Awang, 2018). 
INTERNATIONAL JOURNAL OF ACADEMIC RESEARCH IN BUSINESS AND SOCIAL SCIENCES Vol. 10, No. 8, 2020, E-ISSN: 2222-6990 @ 2020 HRMARS

Table 6: Types of validity and its threshold

\begin{tabular}{|c|c|c|c|c|}
\hline Validity & & Name of Category & Threshold & Sources \\
\hline \multirow[t]{4}{*}{ Construct Validity } & Fitness Indexes & Absolute Fit & RMSEA $<0.08$ & Awang et al. \\
\hline & & Incremental Fit & $\mathrm{CFA} \& \mathrm{TLI}$ & 2015 \\
\hline & & Parsimonious Fit & $>0.9$ & \\
\hline & & & Chisq/df $<3.0$ & \\
\hline \multirow[t]{3}{*}{ Convergent Validity } & Average & & $>0.5$ & Afthanorhan et al., \\
\hline & Variance & & & 2018, 2019 \\
\hline & Extracted (AVE) & & & \\
\hline Discriminant & Discriminant & & & \\
\hline Validity & $\begin{array}{l}\text { Validity Index } \\
\text { Summary }\end{array}$ & & & \\
\hline Composite & $\mathrm{CR}$ & & $>0.6$ & Awang \\
\hline Reliability & & & & 2014,2015 \\
\hline
\end{tabular}

The Assessment of Normality of the Items

Initially, the distribution of items for measuring the EE construct ought to be evaluated. Table 7 displayed the evaluation of normality the distribution from the text-output of IBM-SPSS-AMOS by using the skewness of the distribution within the Maximum Likelihood Estimator (MLE). In order to be adequate for normally distributed, the skewness values should plunge in the range between -1.5 to 1.5 for all items (Awang et al., 2018).

Table 7: The assessment of normality of the items

\begin{tabular}{lllllll}
\hline Variable & Min & Max & Skew & C.R. & Kurtosis & C.R. \\
\hline C13 & 2.000 & 5.000 & .006 & .047 & 2.916 & 11.918 \\
C12 & 2.000 & 5.000 & .213 & 1.743 & 2.797 & 11.433 \\
C11 & 1.000 & 5.000 & -.580 & -4.741 & 3.404 & 13.916 \\
C9 & 2.000 & 5.000 & -.018 & -.147 & 2.280 & 9.320 \\
C8 & 1.000 & 5.000 & -.706 & -5.774 & 1.153 & 4.711 \\
C7 & 3.000 & 5.000 & .530 & 4.335 & .936 & 3.828 \\
C5 & 2.000 & 5.000 & .180 & 1.469 & 1.520 & 6.211 \\
C4 & 2.000 & 5.000 & .433 & 3.537 & 3.379 & 13.814 \\
C2 & 2.000 & 5.000 & -.184 & -1.504 & 2.791 & 11.409 \\
C1 & 3.000 & 5.000 & .655 & 5.353 & .360 & 1.471 \\
Multivariate & & & & & 96.345 & 62.268 \\
\hline
\end{tabular}

The study realized that all skewness values plunge within the range between -1.5 to 1.5 by referring to Table 7. Hence, the data distribution for items measuring the EE construct can prove that it accomplished the normality assumption of parametric statistical analysis. 
INTERNATIONAL JOURNAL OF ACADEMIC RESEARCH IN BUSINESS AND SOCIAL SCIENCES Vol. 10, No. 8, 2020, E-ISSN: 2222-6990 @ 2020 HRMARS

Table 8: Construct validity

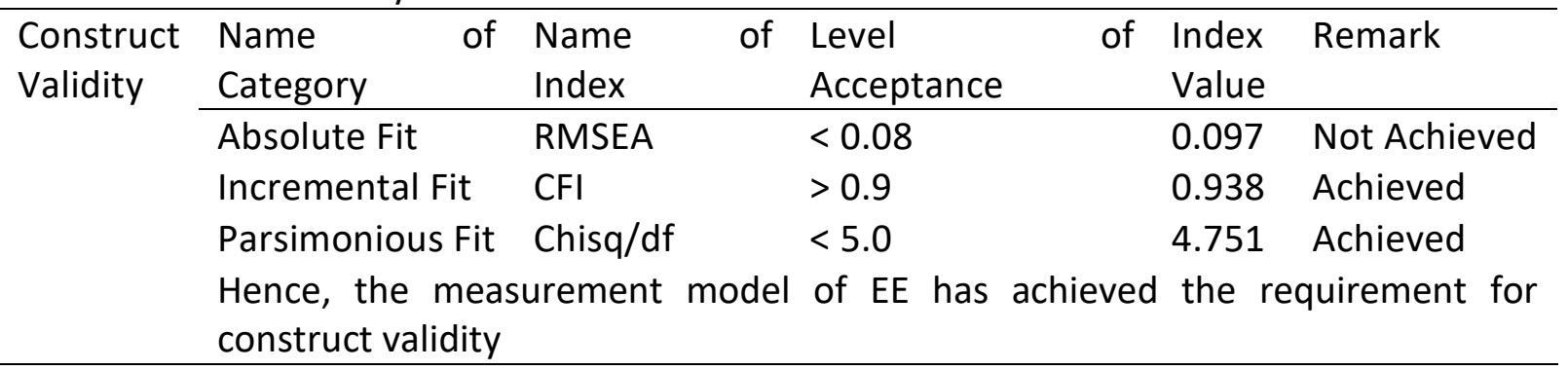

Table 8 indicated the result for Absolute Fit (RMSEA $=0.097)$, Incremental Fit $(C F I=0.938)$ and Parsimonious Fit (Chisq/df $=4.751$ ) correspondingly. Even though the index value of RMSEA does not reach the required acceptance level (slightly higher than 0.08), but the model does achieve another two index which is CFI and Chisq/df. As Afthanorhan (2013) mentioned that at least one fitness index is used from each category model fit, therefore the model still considers fit. Hence, the measurement model of EE has met the requirement for construct validity.

Table 9: Composite reliability, convergent validity and discriminant validity

\begin{tabular}{|c|c|c|c|c|c|c|}
\hline Construct & Item & $\begin{array}{l}\text { Factor } \\
\text { Loading }\end{array}$ & $\begin{array}{ll}\text { CR } & \text { (above } \\
0.6) & \end{array}$ & $\begin{array}{ll}\text { AVE } & \text { (above } \\
0.5) & \end{array}$ & $\sqrt{\text { AVE }}$ & $\begin{array}{l}\text { Convergent } \\
\text { Validity } \\
\text { CR > AVE } \\
\text { AVE > } 0.5\end{array}$ \\
\hline \multirow[t]{3}{*}{$\mathrm{EE}$} & EE1 & 0.98 & 0.90 & 0.78 & 0.88 & Yes \\
\hline & EE2 & 0.81 & & & & \\
\hline & EE3 & 0.84 & & & & \\
\hline \multirow[t]{5}{*}{ EE1 } & $\mathrm{C} 1$ & 0.73 & 0.84 & 0.52 & 0.72 & Yes \\
\hline & $\mathrm{C} 2$ & 0.70 & & & & \\
\hline & C4 & 0.76 & & & & \\
\hline & $\mathrm{C} 5$ & 0.65 & & & & \\
\hline & $\mathrm{C7}$ & 0.75 & & & & \\
\hline \multirow[t]{2}{*}{ EE2 } & $\mathrm{C} 8$ & 0.67 & 0.73 & 0.60 & 0.77 & Yes \\
\hline & C9 & 0.87 & & & & \\
\hline \multirow[t]{3}{*}{ EE3 } & C11 & 0.79 & 0.83 & 0.62 & 0.79 & Yes \\
\hline & C12 & 0.76 & & & & \\
\hline & C13 & 0.81 & & & & \\
\hline
\end{tabular}

The result of the test of reliability and validity for testing the measurement mode displayed in Table 9. The composite reliability of EE, EE1, EE2, and EE3 are $0.90,0.84,0.73$, and 0.83 separately, which meet the requirement (above 0.6). Whereas the result AVE of EE, EE1, EE2, and EE3 are 0.78, $0.52,0.60$, and 0.62 singly, which also achieve the requirement (above 0.5 ). By applying the CFA approach, the result well performs after achieving all the requirements of the measurement model. The study displays that the reliability of CR meets the requirement, convergent validity as well as the discriminant validity. 


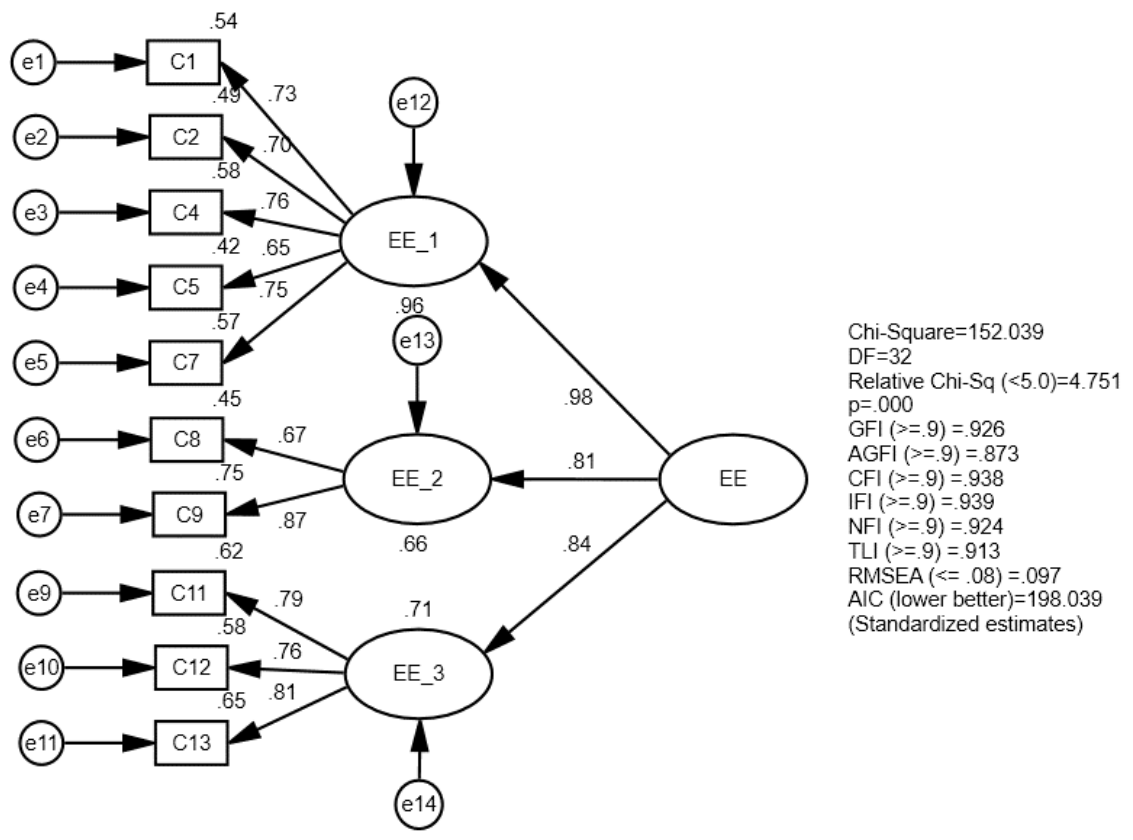

Figure 2: CFA results for $\mathrm{EE}$

The second-order construct for the measurement model of EE demonstrated in Figure 2. This construct has three components which are EE1 represents dedication, EE2 represents absorption, and EE3 represents vigor.

Whereas discriminant validity is another validity requirement which also needs to be tested. The intensity of the correlation between these three components requests to be examined since $\mathrm{EE}$ is a construct with three components in second-order. If the correlation coefficient between the components does not exceed 0.85 , the discriminant validity for the EE construct is accomplished (Noor, Aziz, Mostapa \& Awang, 2015). The correlation coefficient between the components is considered and organized in Figure 3. 


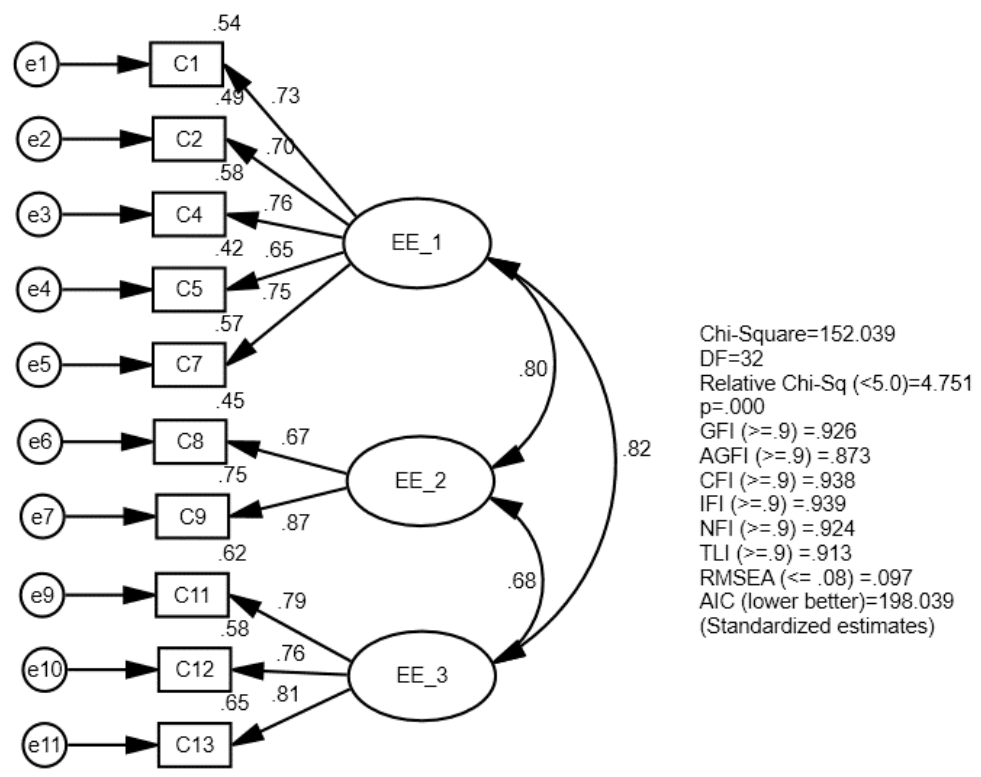

Figure 3: The assessment of convergent validity for EE construct

The review of discriminant validity for the EE construct exhibited in Figure 3. The correlation coefficient between EE1, EE2, and EE3 figured by the IBM-SPSS-AMOS. The results designate the correlation coefficients between all components are $0.80,0.68$, and 0.82 which do not exceed 0.85 . Accordingly, the discriminant validity accomplished by the measurement model for the EE construct.

\section{Conclusion}

Overall, this study attempt to develop and validate the indicator connected to EE in the vocational college context. The EFA procedure has been done to test the requirement for KMO measure of sampling adequacy, Bartlett's Test for sphericity, and Cronbach's Alpha for internal reliability. While the required fitness and the reliability and validity test has been achieved by using the CFA procedure. For future research, this measurement model could be measured with the goal that the following study will be counted in this model.

\section{Contribution of the Study}

The contextual contribution of this study will be the EE construct among vocational colleges' lecturers in Malaysia. In the meanwhile, the findings can help the employer to reflect on themselves especially their leadership and practices to enhance EE among the lecturers in vocational colleges. Furthermore, this study recommending validating the measurement item on EE in Malaysia which 
INTERNATIONAL JOURNAL OF ACADEMIC RESEARCH IN BUSINESS AND SOCIAL SCIENCES

Vol. 10, No. 8, 2020, E-ISSN: 2222-6990 @ 2020 HRMARS

could be a crucial element and dependable wellspring of data for guiding related researchers to brawl the EE research in the future particularly in the educational context.

\section{Limitation and Recommendation}

It could not be dexterous to abridge for the entire Malaysian lecturers' population as far as their EE status since the study only focuses on the North Zone of Malaysia. Subsequently, further research can be performed in another zone of Malaysia to provide a big and clear picture of lecturers' involvement in their daily job scope. Besides, the following researcher can compare the current EE instruments with The Gallup Workplace Audit (GWA) and ISA engagement scale to gather the similarities and differences of the EE instrument in detail.

\section{Acknowledgment}

Acknowledgment to my supervisor, co-supervisor, and friends who have guided me in conducting this research.

\section{Corresponding Author}

Oh Zi Jian, Faculty of Management and Economics, Sultan Idris Education University, Perak, Malaysia E-mail: ohzijian@gmail.com

\section{References}

Abror, A., Patrisia, D., Syahrizal, S., Sarianti, R., \& Dastgir, S. (2020). Self-efficacy, employee engagement, remuneration and employee loyalty in higher education: The role of satisfaction and ocb. International Journal of Advanced Science and Technology, 29(3), 5456-5470.

Afthanorhan, A., Awang, Z., Rashid, N., Foziah, H., \& Ghazali, P. (2019). Assessing the effects of service quality on customer satisfaction. Management Science Letters, 9(1), 13-24.

Afthanorhan, A., Awang, Z., Salleh, F., Ghazali, P., \& Rashid, N. (2018). The effect of product quality, medical price and staff skills on patient loyalty via cultural impact in medical tourism. Management Science Letters, 8(12), 1421-1424.

Afthanorhan, W. M. A. B. W. (2013). A comparison of partial least square structural equation modeling (PLS-SEM) and covariance based structural equation modeling (CB-SEM) for confirmatory factor analysis. International Journal Engineering and Science Innovative Technologies (IJESIT), 2(5), 8.

Atcıoğlu, E., \& Köse, A. (2018). The relationship between the levels of teachers' and administrators' work engagement and the effectiveness of the schools. International Journal of Eurasia Social Sciences, 9(32), 915-947.

Awang, Z. (2012). Structural equation modeling using AMOS graphics. Penerbit Universiti Teknologi MARA.

Awang, Z. (2014). A handbook on SEM for academicians and practitioners: the step by step practical guides for the beginners. Bandar Baru Bangi, MPWS Rich Resources.

Awang, Z. (2015). SEM Made Simple: A Gentle Approach to Learning Structural Equation Modelling. Bandar Baru Bangi, MPWS Rich Resources.

Awang, Z., Afthanorhan, A., Mohamad, M., \& Asri, M. A. M. (2015). An evaluation of measurement model for medical tourism research: the confirmatory factor analysis approach. International Journal of Tourism Policy, 6(1), 29-45. 
INTERNATIONAL JOURNAL OF ACADEMIC RESEARCH IN BUSINESS AND SOCIAL SCIENCES

Vol. 10, No. 8, 2020, E-ISSN: 2222-6990 @ 2020 HRMARS

Awang, Z., Ahmed, U., Hoque, A. S. M. M., Siddiqui, B. A., Dahri, A. S., \& Muda, H. (2017a, October 07-08). The Mediating Role of Meaningful Work in the Relationship between Career Growth Opportunities and Work Engagement. International Academic Conference on Business and Economics (IACBE 2017), Faculty of Economics and Management Sciences (FESP), Universiti Sultan Zainal Abidin (UniSZA), Malaysia.

Awang, Z., Hoque, A. S. M. M., Muda, H., \& Salleh, F. (2017b). The Effects of Crowdfunding on Entrepreneur's Self-Belief. International Academic Conference on Business and Economics (IACBE 2017), Faculty of Economics and Management Sciences (FESP), Universiti Sultan Zainal Abidin (UniSZA), Malaysia.

Awang, Z., Lim, S. H., \& Zainudin, N. F. S. (2018). Pendekatan mudah SEM: Structural Equation Modelling. Selangor: MPWS Rich Publication.

Baistaman, J., Awang, Z., Afthanorhan, A., \& Abdul Rahim, M. Z. (2020). Developing and validating the measurement model for financial literacy construct using confirmatory factor analysis. Humanities \& Social Sciences Reviews, 8(2), 413-422.

Bohlander, G. W., \& Snell, S. A. (2013). Principles of human resource management (16th ed.). South Western: Cengage Learning.

Buric, I., Cvijetovic, J., \& Macuka, I. (2017). Personality, work engagement and job satisfaction: The mediational role of disappointment in the educational system. Suvremena Psihologija, 20(1), 7-22.

Chartered Institute of Personnel and Development (CIPD). (2007). Employee engagement. Retrieved August 17, 2018 from http://www.cipd.co.uk/subjects/empreltns/general/empengmt.htm?lsSrchRes=1

Darwish, S., Abdo, H., \& AlShuwaiee, W. M. (2018). Opportunities, challenges and risks of transition into renewable energy: the case of the Arab Gulf Cooperation Council. International Energy Journal, 18(4).

Dessler, G. (2013). Human resource management. USA: Pearson Education.

Duntemen, G. H. (1989). Principles components analysis: Quantitative applications in the social sciences. California: Sage Publications, Inc.

Field, A. (2006). Discovering statistics using SPSS. London: Sage Publications Ltd.

Gallup. (2002). The high cost of disengaged employees. Gallup Business Journal. Retrieved from http://businessjournal.gallup.com/content/247/the-high-cost-of-disengagedemployees.aspx

Gallup. (2013). Worldwide, 13\% of Employees are engaged at work. State of the Global Workplace. Retrieved from http://doi,org/10.1073/pnas.0703993104

Gebauer, J., \& Lowman, D. (2009). Closing the engagement gap: How great companies unlock employee potential for superior results. New York: Portfolio.

Hair, J., Anderson, R. E., Tatham, R. L., \& Black, W. C. (1998). Multivariate Data Analysis (5th ed.). Upper Saddle River, NJ: Prentice Hall.

Hair, J., Black, B., Babin, B., Anderson, R., \& Tatham, R. (2006). Multivariate Data Analysis (6th ed.). Upper Saddle River, NJ: Prentice-Hall.

Harter, J. K., Schmidt, F. L., \& Hayes, T. L. (2002). Business-unit-level relationship between employee satisfaction, employee engagement, and business outcomes: A meta-analysis. Journal of Applied Psychology, 87, 268-279. 
INTERNATIONAL JOURNAL OF ACADEMIC RESEARCH IN BUSINESS AND SOCIAL SCIENCES Vol. 10, No. 8, 2020, E-ISSN: 2222-6990 @ 2020 HRMARS

Hoque, A. S. M. M., \& Awang, Z. (2016a). The Sway of Entrepreneurial Marketing on Firm Performance: Case of Small and Medium Enterprises (SMES) in Bangladesh, Terengganu International Business and Economics Conference (TiBEC-V), (pp. 174-194). Universiti Teknologi Mara (UiTM), Terengganu, Malaysia.

Hoque, A. S. M. M., \& Awang, Z. (2016c, October 8-10). The Impact of Marketing Strategy on Small and Medium Scale Enterprises (SMEs): Case Study in Bangladesh. International Postgraduate Research Conference (IPRC 2016), Universiti Sultan Zainal Abidin (UniSZA), Gong Badak Campus, Kuala Terengganu, Malaysia.

Hoque, A. S. M. M., Awang, Z., \& Siddiqui, B. A. (2017a). Technopreneurial Intention among University Students of Business Courses in Malaysia: A Structural Equation Modeling. International Journal of Entrepreneurship and Small \& Medium Enterprise (IJESME), 4, 1-16.

Hoque, A. S. M. M., Awang, Z., Baharu, S. M. A. T., \& Siddiqui, B. A. (2018a). Upshot of Generation 'Z' Entrepreneurs' E-lifestyle on Bangladeshi SME Performance in the Digital Era. International Journal of Entrepreneurship and Small \& Medium Enterprise (IJESME).

Hoque, A. S. M. M., Awang, Z., Jusoff, K., Salleh, F., \& Muda, H. (2017b). Social Business Efficiency: Instrument Development and Validation Procedure using Structural Equation Modelling, International Business Management, 11(1), 222-231.

Hoque, A. S. M. M., Awang, Z., Siddiqui, B. A., \& Sabiu, M. S. (2018c). Role of Employee Engagement on Compensation System and Employee Performance Relationship among Telecommunication Service Providers in Bangladesh. International Journal of Human Resource Studies, 8(3), 19-37. doi: http://dx.doi.org/10.5296/ijhrs.v8i3.13081

Hoque, A. S. M. M., Gwadabe, U. M., \& Rahman, M. A. (2017c). Corporate Entrepreneurship Upshot on Innovation Performance: The Mediation of Employee Engagement. Journal of Humanities, Language, Culture and Business, 1(6), 54-67.

Hoque, A. S. M. M., \& Awang, Z. (2016b). Exploratory factor analysis of entrepreneurial marketing: Scale development and validation in SME context of Bangladesh, International Social Sciences and Tourism Research Conference (pp. 20-22). UniSZA, Terengganu, Malaysia.

Hoque, A. S. M. M., \& Awang, Z. (2019). Does gender difference play moderating role in the relationship between entrepreneurial marketing and Bangladeshi SME performance? Accounting, 5(1).

Ibnu Ruslan, R., Islam, M. A., Noor, M. I., \& Mat, N. (2016). Employee engagement among assistant registrars in public institutions of higher education in Malaysia: A descriptive study. International Journal of Business and Technopreneurship, 6(3), 439-450.

linasikin, Murni, S., \& Akbar, M. (2019). Transformational leadership and teacher's employee engagement of state vocational high schools. International Journal of Recent Technology and Engineering, 8(2), 385-389.

Janssen, M., Heerkens, Y., Van Der Heijden, B., Korzilius, H., Peters, P., \& Engels, J. (2020). A study protocol for a cluster randomised controlled trial on mindfulness-based stress reduction: Studying effects of mindfulness-based stress reduction and an additional organisational health intervention on mental health and work-related perceptions of teachers in Dutch secondary vocational schools. Trals, 21(1), 376.

Kahn, W. A. (1990). Psychological conditions of personal engagement and disengagement at work. Academy of Management Journal, 33, 692-724.

Kaldeen, M., \& Maran, K. (2020). Impact of knowledge management process on knowledge-worker 
INTERNATIONAL JOURNAL OF ACADEMIC RESEARCH IN BUSINESS AND SOCIAL SCIENCES

Vol. 10, No. 8, 2020, E-ISSN: 2222-6990 @ 2020 HRMARS

productivity in state universities in Sri Lanka: A mediating role of employee engagement. Test Engineering and Management, 83, 8331-8342.

Kerlinger, F. N., \& Lee, H. B. (2000). Foundations of behavioural research (4th ed.). Holt, NY: Harcourt College Publishers.

Kinicki, A., \& Fugate, M. (2016). Organizational behavior, a practical, problem solving approach. New York: McGraw-Hill Education.

Kola, J., \& Challapalli, P. (2019). A study on relationship between emotional intelligence, ethical ideology, job performance and employee engagement in telangana autonomous engineering colleges. Quality - Access to Success, 20(168), 73-78.

Kung-Tech, W., Omar, J., Yassin, S. M., Mustafa, M. C., Abdullah, N., Rahmatullah, B., \& Samuri, S. M. (2019). Development of quality early childhood care and education (QECCE) scale: Factor structural and psychometric properties. International Journal of Learning, Teaching and Educational Research, 18(11), 385-396.

Lewis-Beck, M. S. (1994). Factor analysis and related techniques. London: Sage Publication, Ltd.

Macey, W. H., Schneider, B., Barbara, K. M., \& Young, S. A. (2009). Employee engagement: Tools for analysis, practice and competitive advantage. UK: Wiley-Blackwell.

Latha, M. C., Mohanthy, A., \& Ramakrishna, N. (2020). Root cause analysis of faculty dis-engagement in higher education sector using fish bone diagram. International Journal of Scientific and Technology Research, 9(3), 1483-1488.

Mohamad, M., Ali, N. A. M., \& Awang, Z. (2018). The impact of life satisfaction on substance abuse: delinquency as a mediator. International Journal of Adolescence and Youth, 23(1), 25-35.

Mora, L., Hakim, A. R., Agustriyana, D. (2020). Attitude toward compensation and employee engagement of organization citizenship behavior (Study of staff employees of one mining company in kalimantan). International Journal of Psychosocial Rehabilation, 24(7). 3327-3333.

Muthuveloo, R., Basbous, O. K., Teoh, A. P., \& Choi, S. L. (2013). Antecedents of employee engagement in manufacturing sector. American Journal of Applied Sciences, 10(12), 15461552.

Nasir, M. N. M., Mohamad, M., Ghani, N. I. A., \& Afthanorhan, A. (2020). Testing mediation roles of place attachment and tourist satisfaction on destination attractiveness and destination loyalty relationship using phantom approach. Management Science Letters, 10(2), 443-454. Retrieved from https://doi.org/10.5267/j.msl.2019.8.026

Nienaber, H. (2019). Employee engagement: Driving strategy implementation through dimensions of organisation. Journal of Management \& Organization, 1-21. doi:10.1017/jmo.2019.22

Noor, N. M., Aziz, A. A., Mostapa, M. R., \& Awang, Z. (2015). Validation of the Malay version of the Inventory of Functional Status after Childbirth questionnaire. BioMed Research International. Retrieved from https://doi.org/10.1155/2015/972728

Nunnally, J. C. (1978). Psychometric Theory (2nd ed.). New York: McGraw-Hill.

Nunnally, J. C., \& Bernstein, I. H. (1994). Psychometric theory (3rd ed.). New York: McGraw-Hill.

Pallant, J. (2007). SPSS survival manual: A step by step guide to data analysis using SPSS for windows (3rd ed.). Open University Press.

Puteh, F., Kaliannnan, M., \& Alam, N. (2015). Assessing Gen Y impact on organizational performance: An analysis from top management perspective. Journal of Administrative Science, 12, 47-59. 
INTERNATIONAL JOURNAL OF ACADEMIC RESEARCH IN BUSINESS AND SOCIAL SCIENCES

Vol. 10, No. 8, 2020, E-ISSN: 2222-6990 @ 2020 HRMARS

Rahlin, N. A., Awang, Z., Afthanorhan, A., \& Aimran, N. (2019). The Art of Covariance Based Confirmatory Factor Analysis: Evidence from SME'S. International Journal of Innovation, Creativity and Change, 5(2).

Rashid, S., \& Harif, M. A. A. (2015). Employee engagement: A qualitative research on critical factors within Malaysia's SME businesses. First Asia Pacific Conference on Contemporary Research, 54-65.

Schaufeli, W. B., \& Baker, A. P. (2010). Work engagement: A handbook of essential theory and research. USA: Psychology Press.

Schaufeli, W., Salanova, M., Gonzalez-Roma, V., \& Bakker, A. (2002). The measurement of burnout and engagement: a confirmatory factor analytic approach. Journal of Happiness Studies, 3(1), 71-92.

Sekaran, U., \& Roger J. B. (2013). Research Methods for Business: A Skill Building Approach (6th ed.). Wiley.

Tritch, T. (2003). Engagement drives result at new century. Gallup Management Journal, 1-7. Retrieved from https://www.nova.edu/ie/ice/forms/engagement_drives_results.pdf

Yildiz, D., Temur, G. T., Beskese, A., \& Bozbura, F. T. (2020). Evaluation of positive employee experience using hesitant fuzzy analytic hierarchy process. Journal of Intelligent and Fuzzy Systems, 38(1), 1043-1058. 